\title{
Lead, Zinc and Cadmium Accumulation, and Associated Health Risks, in Maize Grown near the Kabwe Mine in Zambia in Response to Organic and Inorganic Soil Amendments
}

\author{
Patricia N. Mwilola ${ }^{1}$, Ikabongo Mukumbuta ${ }^{1,2, *} \mathbb{}$, Victor Shitumbanuma ${ }^{1}$, \\ Benson H. Chishala ${ }^{1}$, Yoshitaka Uchida ${ }^{3}{ }^{\oplus}$, Hokuto Nakata ${ }^{2}\left({ }^{\circ}\right.$, Shouta Nakayama ${ }^{2}$ and \\ Mayumi Ishizuka ${ }^{2}$ \\ 1 Department of Soil Science, School of Agricultural Sciences, University of Zambia, \\ Lusaka P.O. Box 32379, Zambia; mwilolanalishebo@gmail.com (P.N.M.); vshitumbanuma@unza.zm (V.S.); \\ bchishala@unza.zm (B.H.C.) \\ 2 Faculty of Veterinary Medicine, Hokkaido University, Kita 18, Nishi 9, Kita-Ku, Sapporo 060-0809, Japan; \\ hokuto.nakata@vetmed.hokudai.ac.jp (H.N.); shouta-nakayama@vetmed.hokudai.ac.jp (S.N.); \\ ishizum@vetmed.hokudai.ac.jp (M.I.) \\ 3 Research Faculty of Agriculture, Hokkaido University, Kita 9, Nishi 9, Kita-ku, Sapporo 060-8589, Japan; \\ uchiday@chem.agr.hokudai.ac.jp \\ * Correspondence: ikabongo1@gmail.com; Tel.: +260-961-486-377
}

Received: 29 September 2020; Accepted: 1 December 2020; Published: 4 December 2020

\begin{abstract}
Health risks due to heavy metal (HM) contamination is of global concern. Despite concerns of high levels of HMs in soils near Kabwe mine in Zambia, edible crop production is common, posing potential health risks. This study assessed the potential of chicken manure (CM), triple superphosphate (TSP) and a blended fertilizer (BF; consisting of Nitrogen, Phosphorous and Potassium (NPK) fertilizer and composted chicken manure) to reduce lead $(\mathrm{Pb})$, zinc $(\mathrm{Zn})$ and cadmium $(\mathrm{Cd})$ in soils and their accumulation in maize grown near the Kabwe mine. Maize was grown to maturity and its HM concentrations and associated health risk indices were calculated. All soil amendments decreased bioavailable soil $\mathrm{Pb}$ concentrations by $29-36 \%$, but only CM decreased $\mathrm{Zn}$, while the amendments increased or had no effect on $\mathrm{Cd}$ concentrations compared to the control. The amendments reduced $\mathrm{Pb}(>25 \%)$ and $\mathrm{Zn}$ concentrations ( $>18 \%)$ in the maize stover and grain. However, Cd concentrations in maize grain increased in the BF and TSP treatments. Bioaccumulation factors showed that Cd had the highest mobility from the soil into maize stover and grain, indicating the need for greater attention on $\mathrm{Cd}$ in Kabwe despite its apparently lower soil concentration compared to $\mathrm{Pb}$ and $\mathrm{Zn}$. The hazard quotients for $\mathrm{Pb}$ and $\mathrm{Cd}$ were much greater than one, indicating a high risk of possible exposure to toxic levels by people consuming maize grain grown in this area. This study demonstrated the significant potential of manure and phosphate-based amendments to reduce $\mathrm{Pb}$ and $\mathrm{Zn}$, and to some extent $\mathrm{Cd}$, uptake in maize grain and consequently reduce associated health risks.
\end{abstract}

Keywords: legacy mining; heavy metals; soil amendments; maize; health risks

\section{Introduction}

Contamination of the environment due to heavy metals (HMs) from mining and other industrial activities is of major concern globally due to their effect on water and food quality and the resulting effect on human healthy [1-3]. Heavy metals accumulate in soils following the disposal of tailings, dust emission, through water transport or pesticide use [4-8]. Food crops can accumulate high 
amounts of HMs through soil-plant uptake, leading to food contamination and significant human health risks [8-12]. Food crop consumption has been reported as one of the major pathways for human exposure to HMs [11]. Furthermore, due to being non-biodegradable, HMs can accumulate in the human body even when their concentrations in the ingested food are low.

Heavy metals pose a significant effect on the health of soils, plants, animals and humans $[4,8,13]$. Among the HMs, lead $(\mathrm{Pb})$ and cadmium $(\mathrm{Cd})$ have serious adverse effects on plant growth, and human and animal health when ingested. $\mathrm{Cd}$ is reported to be carcinogenic and highly toxic to humans and animals [14] and leads to reduced germination and growth of plants [15]. Pb affects neurodevelopment of humans especially children [14,16] and inhibits plant growth. Unlike $\mathrm{Pb}$ and $\mathrm{Cd}$, Zinc (Zn) is an essential plant nutrient but at elevated concentrations it has adverse effects on soil microorganisms, plants and animal health [5,15] and decreases soil quality [17].

Different strategies such as soil inversion or replacement [18], phytoremediation [19], use of raised garden beds [20], use of specific plants/crops [21] and addition of soil amendments [22-24], have been used to minimize accumulation of HMs in food crops and the resulting human exposure. However, phytoremediation takes long to show positive effects [25] and other methods such as soil replacement are very costly [26]. Soil amendments, such as manure and phosphate-fertilizers can be both effective and cheaper $[20,26]$ and therefore more suited for poorer countries. Soil amendments such as manure, compost and phosphorous-based fertilizers have been proposed and shown to immobilize HMs in soil and reduce plant uptake [4,22-24,27,28]. Organic amendments such as animal manure immobilize HMs through chelation, formation of insoluble complexes, adsorption on charged functional groups and cation exchange [4,22,29]. Phosphate amendments immobilize HMs by formation of insoluble compounds such as pyromorphite [22,24].

In Kabwe, a town in central Zambia, mining was the main economic activity for several years but despite the closure of the mine, small-scale mining, including scavenging by local residents, is still widespread [30,31]. These activities, combined with poor environmental management have resulted in high levels of HMs such as $\mathrm{Pb}, \mathrm{Cd}$ and $\mathrm{Zn}$ in many parts of the town [30,32]. Gardening and food crop production in the areas close to the mine is common and therefore, posing a high risk of human exposure to toxic levels of these HMs through food crop consumption. To date, there is limited information on the extent of this risk and on possible management and mitigation measures to remedy the problem [30]. Although inorganic and organic amendments, such as phosphate and manure, have shown potential to mitigate the accumulation of HMs in food crops [4,20,22-24], there is still lack of site-specific information in many African countries like Zambia [20,33]. In-situ field studies like this one are therefore still very crucial to fully understand the interaction between soil amendments and HMs in diverse settings and locations [20]. Furthermore, to the best of our knowledge, there haven't been in-situ field experiments in the vicinity of the Kabwe mine to assess the extent of the human health risks through maize consumption and potential mitigation measures.

The main goals of this study were to: (i) assess the levels of accumulation of $\mathrm{Pb}, \mathrm{Zn}$ and $\mathrm{Cd}$ in the roots, stover and grain of maize (Zea mays), a crop widely grown and consumed in the study area, and the associated health risks, based on the joint United Nations Food and Agricultural Organization (FAO) and World Health Organization (WHO) limits for human health, and (ii) evaluate the effect of phosphate-bearing organic and inorganic soil amendments: chicken manure, triple super phosphate and an NPK fertilizer mixed with chicken manure on the bioavailable concentrations of $\mathrm{Pb}, \mathrm{Zn}$ and $\mathrm{Cd}$ in the soil and their uptake by maize. We hypothesized that although the maize could be contaminated due to proximity to the mine, the HM concentrations and the health risks of consuming the maize can be significantly reduced after applying amendments to the soils.

\section{Materials and Methods}

\subsection{Study Site}

This study was conducted on a field located within $500 \mathrm{~m}$ from the former $\mathrm{Pb} / \mathrm{Zn}$ mine in Kabwe town, central Zambia $\left(14^{\circ} 27^{\prime} 28.3^{\prime \prime} \mathrm{S}, 28^{\circ} 27^{\prime} 37^{\prime \prime} \mathrm{E}\right)$. Before this study, this field had been used for 
growing maize and other crops by local residents. The permission to use the land for this study was granted by the Kabwe municipal council.

This area receives an average of $900 \mathrm{~mm}$ rainfall annually with a mean annual temperature of $20.2^{\circ} \mathrm{C}$ [30]. The soils at this site are classified as Chromic Haplic Lixisol [34]. The main properties of the soil and amendments are shown in Table 1.

Table 1. Soil and amendment characteristics.

\begin{tabular}{|c|c|c|c|c|}
\hline Parameter & Soil & Manure & BF & TSP \\
\hline Total $\mathrm{Pb}\left(\mathrm{mg} \mathrm{kg}^{-1}\right)$ & $8810 \pm 310$ & - & - & - \\
\hline Total Zn (mg kg-1) & $1102 \pm 203$ & - & - & - \\
\hline Total Cd $\left(\mathrm{mg} \mathrm{kg}^{-1}\right)$ & $260 \pm 17$ & - & - & - \\
\hline Total $\mathbf{P}$ & $21.0 \mathrm{mg} \mathrm{kg}^{-1}$ & $1.2 \%$ & $20 \%$ & $46 \%$ \\
\hline Total carbon $(\%)$ & 3.7 & & & \\
\hline Total nitrogen $(\%)$ & 0.28 & 3.0 & 10 & 0 \\
\hline $\mathrm{pH}$ & 5.7 & & & \\
\hline $\mathrm{CEC}\left(\mathrm{cmol}+\mathrm{kg}^{-1}\right)$ & 5.2 & & & \\
\hline
\end{tabular}

CEC is cation exchange capcity; $\mathrm{P}$ is phosphorous; $\mathrm{BF}$ is blended fertilizer (a mixture of NPK fertilizer and chicken manure; TSP is triple super phosphate.

\subsection{Experimental Design}

This study examined the effects of raw chicken manure (CM), triple super phosphate (TSP), and blended fertilizer (BF) - a mixture of inorganic NPK fertilizer (10:20:10) and chicken manure on Pb, $\mathrm{Zn}$ and $\mathrm{Cd}$ immobilization in the soil and uptake in maize. These amendments were chosen in part due to ease of use, high availability in the study site and relatively low cost. Chicken manure was used its raw form as this is the common practice among gardeners in Zambia. Including the un-amended control (CT), there were a total of 16 plots each $4 \times 4 \mathrm{~m}$ in size. Each of the four treatments was replicated four times and arranged in a Latin square design with a space of $0.5 \mathrm{~m}$ left between the plots. The field was ploughed to $\sim 20 \mathrm{~cm}$ depth before application of the amendments. The amount of each amendment applied was aimed at supplying enough phosphate $\left(\mathrm{PO}_{4}\right)$ to immobilize the $\mathrm{Pb}$ within the top $20 \mathrm{~cm}$ soil by converting it to pyromorphite $\left(\mathrm{Pb}_{5}\left(\mathrm{PO}_{4}\right)_{3} \mathrm{C} /\right)$ at $5: 3 \mathrm{~Pb}$ :phosphorous $(\mathrm{P})$ ratio $[4,35]$. Although the soil contains different HMs, the amendments were applied based on the concentration of $\mathrm{Pb}$, the metal of highest concern in the area [30]. The P contents in $\mathrm{CM}, \mathrm{BF}$ and TSP were $1.2 \%$, $20 \%$ and $46 \%$ respectively, resulting in the application of $82 \mathrm{~kg} \mathrm{CM}, 5 \mathrm{~kg}$ BF and $3.2 \mathrm{~kg}$ TSP per plot. The applied amendments were equivalent to 50 ton, 6 ton and 0.9 ton ha ${ }^{-1} \mathrm{CM}, \mathrm{BF}$ and TSP respectively. These application rates of the amendments were similar to those used in other studies [4,23]. Nitrogen equal to that applied in the BF treatment $\left(300 \mathrm{~g} \mathrm{plot}^{-1}, 187 \mathrm{~kg} \mathrm{~N} \mathrm{ha}^{-1}\right)$ was applied in the TSP and CT plots. The amendments were incorporated into the soil to the rooting depth of $20 \mathrm{~cm}[36,37]$.

The maize was planted at 20 and $40 \mathrm{~cm}$ intra- and inter-row spacing. At physiologic maturity, about 125 days after planting, maize plants were harvested and separated into roots, stover and grain. To determine total maize biomass production, maize plants in each plot were weighed and then 10 plants selected for drying used for determination of the moisture content and HM concentration. After drying $\left(\right.$ at $70{ }^{\circ} \mathrm{C}$ ) the roots, stover and grains were ground and homogenized. The HM concentrations in the different plant parts were extracted in $1 \mathrm{M} \mathrm{HNO}_{3}$ after dry ashing [38] and analyzed using a Flame Atomic Adsorption Spectrophotometer (FAAS; AA-6300, Shimadzu, Kyoto, Japan). The FAAS was run using acetylene gas and air as an oxidant at $2.5 \mathrm{~mL} \mathrm{~min}^{-1}$. The detection limit for the FAAS was 0.01, 0.002 and $0.0004 \mathrm{mg} \mathrm{L}^{-1}$ for $\mathrm{Pb}, \mathrm{Zn}$ and $\mathrm{Cd}$ respectively.

\subsection{Determination of Total and Bioavailable $\mathrm{Pb}, \mathrm{Zn}$ and $\mathrm{Cd}$ in Soils}

Soil samples $(0-20 \mathrm{~cm}$ depth) were collected prior to starting the experiment at 10 points within a $50 \times 50 \mathrm{~m}$ field, and in each plot at the end of the experiment. The soils were air-dried, homogenized and then passed through a $2 \mathrm{~mm}$ sieve. The soils were analyzed for total $\mathrm{Pb}$, 
$\mathrm{Zn}$ and $\mathrm{Cd}$ contents extracted using aqua-regia solution (a mixture of nitric acid and hydrochloric acid in 1:3 ratio), and potentially-plant available $\mathrm{Pb}, \mathrm{Zn}$ and $\mathrm{Cd}$ concentrations extracted using diethylentriaminopentanacetic acid triethanolamine (DTPA-TEA) solution buffered at $\mathrm{pH} 7.3$ according to Lindsay and Norvell [39]. The DTPA-TEA extractable HMs are considered as bioavailable for plant uptake in this study [40]. Both the total and potentially-plant available soil $\mathrm{Pb}, \mathrm{Zn}$ and $\mathrm{Cd}$ concentrations were determined using a FAAS.

For quality control, standard reference materials (SRM) 1573a (dried tomato leaves) and 2710a (Montana soil) were used. Additionally, all reagents used for both plant and soil extractions were analytical grade. For every set of sample analysis, a blank, with only the extracting reagent, was run during both the digestion and analysis throughout the experiment, and additionally, all containers were thoroughly washed, immersed in diluted $\mathrm{HNO}_{3}$ for $24 \mathrm{~h}$ and subsequently rinsed with deionized water before use. Standard solutions were used to precondition the FAAS during each analysis. All plant and soil analyses were replicated four times.

\subsection{Determination of Bioaccumulation Factors for $\mathrm{Pb}, \mathrm{Zn}$ and $\mathrm{Cd}$ in Maize Stover and Grain}

The bioaccumulation factor (BAF) is an important index that shows the transfer of HMs and other hazardous materials from the soil into plants [8]. In this study, the BAFs were determined separately for transfer of HMs from soil into the maize stover and from the soil into the maize grain using Equation (1).

$$
\mathrm{BAF}=\mathrm{HM} \text { concentration in stover (or grain)/Soil HM concentration }
$$

\section{5. $\mathrm{Pb}$ and $\mathrm{Cd}$ Dietary Intake and Health Risk Assessment}

The Joint United Nations Food and Agricultural Organization (FAO)/WHO Codex Alimentarius Commission (2018) [41] maximum tolerable intake limits were used as critical values to check the extent to which maize grown in soils near the Kabwe mine pose a risk to the local people. The hazard quotient $(\mathrm{HQ})$ was used to assess the potential risk to human health resulting from maize consumption and was calculated as follows:

$$
\begin{gathered}
\mathrm{HQ}=\mathrm{EI} / \mathrm{TI} \\
\mathrm{EI}=\mathrm{HM} \text { concentration in grain } * \mathrm{Df} * \mathrm{Y} / \mathrm{HBW}
\end{gathered}
$$

where: $\mathrm{EI}$ is the estimated metal intake (weekly for $\mathrm{Pb}$ and monthly for $\mathrm{Cd}$ ) through maize grain consumption; TI represents the safe level of metal exposure through food crop consumption (weekly for $\mathrm{Pb}$ and monthly for $\mathrm{Cd}$ ) [41]; $\mathrm{Df}$ is the average daily consumption of maize grain for an adult in Zambia; HBW is the average human body weight of an adult; $\mathrm{Y}$ is the number of days in a week or month.

In this study, $350 \mathrm{~g}$ was used as the Df [42], $70 \mathrm{~kg}$ as HBW [43] and $0.025 \mathrm{mg} \mathrm{kg}^{-1} \mathrm{HBW}$ as the monthly $\mathrm{Cd}$ and weekly $\mathrm{Pb} \mathrm{TI}$ values [41].

HQ values greater than 1 indicate significant risk to human health, while values less than 1 are considered safer for human health $[10,40]$.

The TI value for $\mathrm{Zn}$ has not been established yet [41,43] and therefore EI and HQ values were not calculated for $\mathrm{Zn}$ in this study.

\subsection{Data Analysis}

All statistical analyses were performed using STATA 13 (Stata Corporation, College Station, TX, USA). The effect of soil amendments on bioavailable $\mathrm{Pb}, \mathrm{Zn}$ and $\mathrm{Cd}$ concentrations in soils, and $\mathrm{Pb}$, $\mathrm{Zn}$ and $\mathrm{Cd}$ concentrations in maize roots, stover and grain were evaluated using one-way ANOVA. Differences among the amendments were tested using Tukey's significance test. Pearson's correlation analysis was used to establish relationships among the bioavailable $\mathrm{Pb}, \mathrm{Zn}$ and $\mathrm{Cd}$ concentrations in soils, $\mathrm{Pb}, \mathrm{Zn}$ and $\mathrm{Cd}$ concentrations in maize roots, stover and grain with maize biomass 


\section{Results}

\subsection{Effect of Soil Amendments on Potentially-Plant Available Pb, Zn and Cd and Maize Biomass Production}

The DTPA-TEA extractable Pb concentrations in the soil decreased by $30 \%, 36 \%$ and $29 \%$ in the CM, TSP and BF treatments respectively, compared to the unamended control plots (Figure 1). In contrast to results for $\mathrm{Pb}, \mathrm{TSP}$ and $\mathrm{BF}$ did not decrease DTPA-TEA extractable $\mathrm{Zn}$ or Cd compared to the un-amended soil (Figure 1). Chicken manure on the other hand decreased concentrations of DTPA-TEA extractable $\mathrm{Zn}$ by $19 \%$ but increased those of $\mathrm{Cd}$ by $10 \%$ compared to the control.

Relative to the control treatment, the maize biomass production significantly increased in the CM and BF amended plots (Table 2). Maize biomass in the TSP plot was higher than that in the control although not statistically significant.
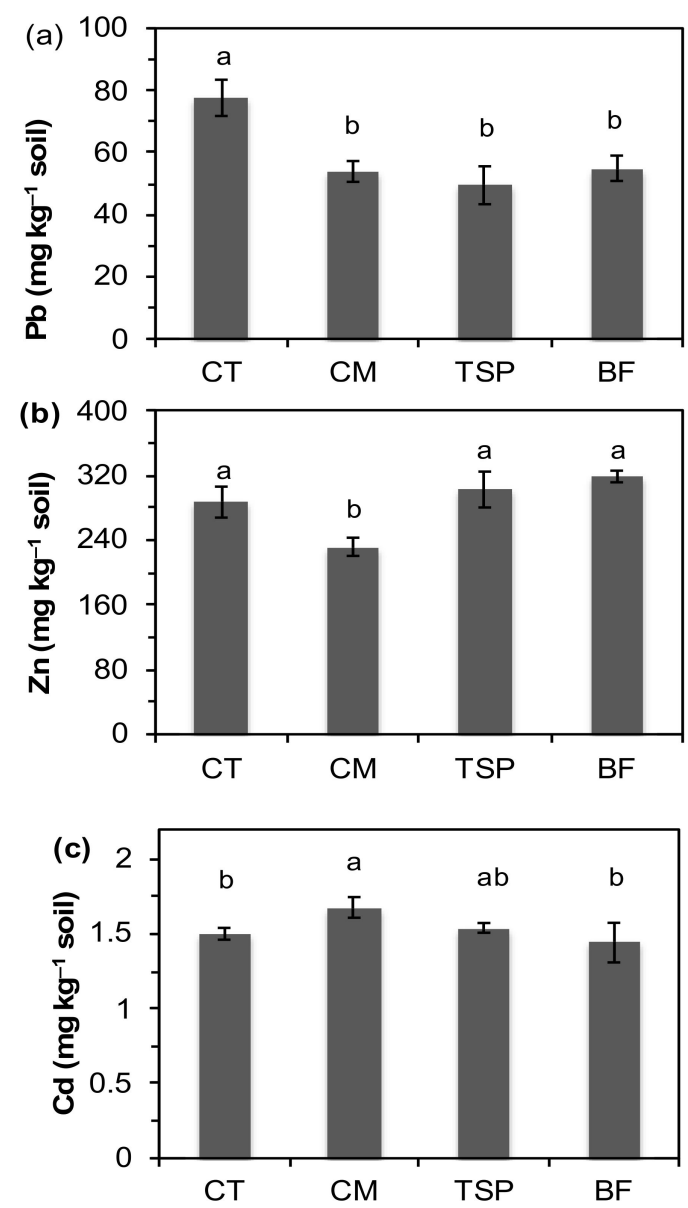

Figure 1. Concentrations of bioavailable: (a) lead $(\mathrm{Pb})$; (b) zinc ( $\mathrm{Zn})$; (c) cadmium $(\mathrm{Cd})$ in the soil at the end of the experiment. CT is the control, CM is chicken manure, TSP is triple superphosphate, $\mathrm{BF}$ is blended fertilizer (a mixture of NPK fertilizer and chicken manure). Bars with different letters are significantly different $(p<0.05)$.

Table 2. Mean maize biomass yield ( \pm standard error) for different treatments.

\begin{tabular}{|c|c|c|c|c|}
\hline & $\mathrm{CT}$ & $\mathrm{CM}$ & TSP & BF \\
\hline Biomass Yield (kg plot $\left.{ }^{-1}\right)$ & $0.9 \pm 0.2^{b}$ & $22.7 \pm 2.2^{\mathrm{a}}$ & $5.2 \pm 0.4^{b}$ & $22.5 \pm 3.7^{\mathrm{a}}$ \\
\hline Biomass Yield $\left(\mathrm{kg} \mathrm{ha}^{-1}\right)$ & $1164 \pm 310^{b}$ & $28,438 \pm 2830^{\mathrm{a}}$ & $6578 \pm 529^{b}$ & $28,092 \pm 4726^{a}$ \\
\hline
\end{tabular}

$\mathrm{CT}$ is the control, CM is chicken manure, TSP is triple superphosphate, BF is blended fertilizer (mixture of NPK fertilizer and chicken manure) treatments. Values with different superscripts within a row indicate significantly different treatment means at $p<0.05$. 


\subsection{Effect Soil Amendments on $\mathrm{Pb}, \mathrm{Zn}$ and $\mathrm{Cd}$ Accumulation in Maize}

Lead concentrations were highest in roots and lowest in the maize grain (Figure 2). Application of TSP and $\mathrm{BF}$ decreased $\mathrm{Pb}$ concentration in roots by more than $75 \%$ with root $\mathrm{Pb}$ concentration averaging 156.2 and $157.1 \mathrm{mg} \mathrm{kg}^{-1}$ in TSP and BF treatments compared to $743.3 \mathrm{mg} \mathrm{kg}^{-1}$ in the control plot. Manure application on the other hand did not decrease root $\mathrm{Pb}$ concentrations and instead resulted in a slight increase. Unlike the concentrations of $\mathrm{Pb}$ in roots, all three soil amendments significantly $(p<0.01)$ reduced $\mathrm{Pb}$ concentrations in the maize stover from $554 \mathrm{mg} \mathrm{kg}^{-1}$ to below $130 \mathrm{mg} \mathrm{kg}^{-1}$, on average, representing a reduction of more than $75 \%$ (Figure 2). In the maize grain, Pb concentration decreased by $27 \%, 76 \%$ and $83 \%$ in the treatments TSP, BF and CM, respectively, compared to the control (Figure 2). The maize grain $\mathrm{Pb}$ concentrations ranged from 27.3-29.0, 3.1-5.3, 20.6-21.6 and 5.8-8.4 mg $\mathrm{kg}^{-1}$ in the un-amended control, CM, TSP and BF treatments, respectively. The $\mathrm{Pb}$ concentrations in the maize grain, from all treatments, were higher than the joint FAO/WHO maximum permissible limit of $0.2 \mathrm{mg} \mathrm{kg}^{-1}$ for human health safety.
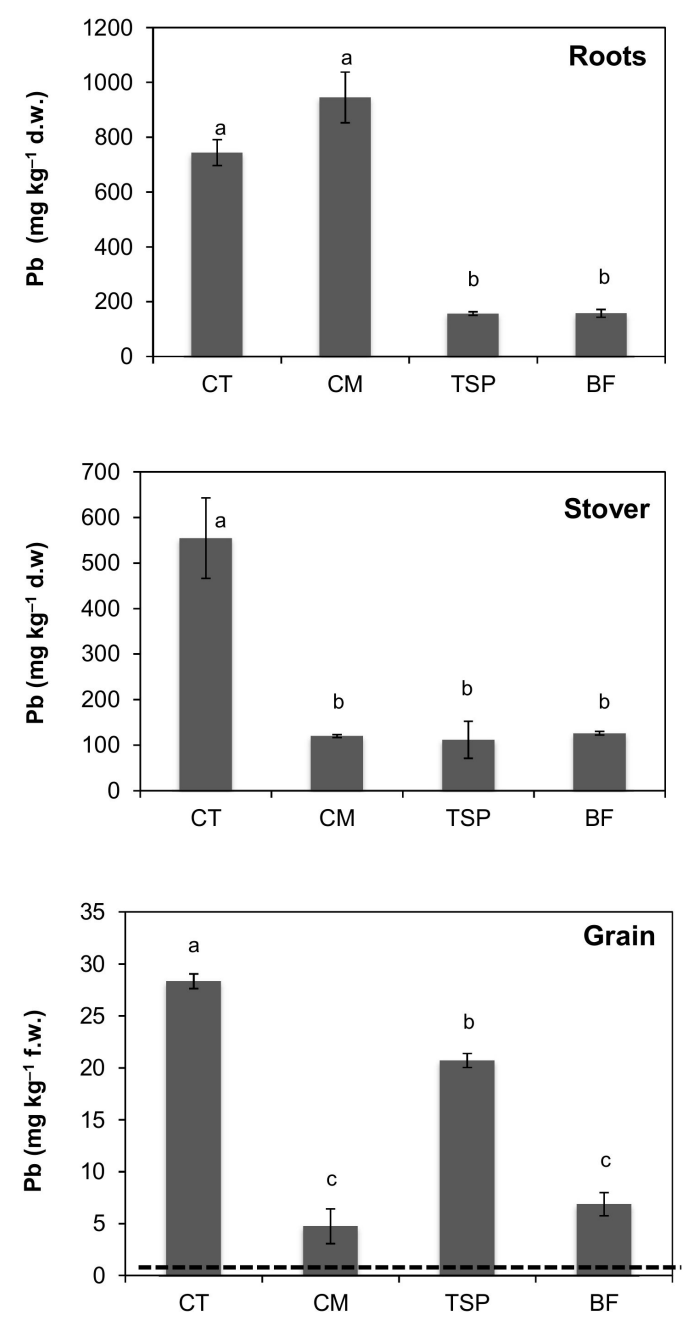

Figure 2. Concentrations of lead $(\mathrm{Pb})$ in maize roots, stover and grain in plots amended with chicken manure (CM), triple superphosphate (TSP) and blended fertilizer (BF; a mixture of NPK fertilizer and chicken manure) compared to the control (CT). The horizontal broken line indicates the FAO/WHO maximum allowable limit of $0.2 \mathrm{mg} \mathrm{Pb} \mathrm{kg}^{-1}$ maize grain for human health. Concentrations in roots and stover are on dry matter weight (d.w) basis, but on fresh weight (f.w) basis in grain. Bars with different letters are significantly different $(p<0.05)$. 
Zinc concentrations in different maize parts generally decreased with soil amendment application (Figure 3). In the roots, the $\mathrm{Zn}$ concentration in the amended soils ranged from $3100-3400 \mathrm{mg}$ $\mathrm{kg}^{-1}$ compared to an average of over $4600 \mathrm{mg} \mathrm{kg}^{-1}$ in the un-amended soils, representing a 26-33\% decrease (Figure 3). Chicken manure and TSP significantly $(p<0.01)$ decreased $\mathrm{Zn}$ concentration in the stover. A significant reduction of $18-29 \%$ in maize grain $\mathrm{Zn}$ concentration was observed in all three soil amendments compared to the control, but there was no significant difference among the three amendments. The maize grain Zn concentrations ranged from 62.4-71.9, 45.2-55.3, 50.9-58.5 and $45.7-49.9 \mathrm{mg} \mathrm{kg}^{-1}$ in the un-amended control, CM, TSP and BF treatments, respectively.
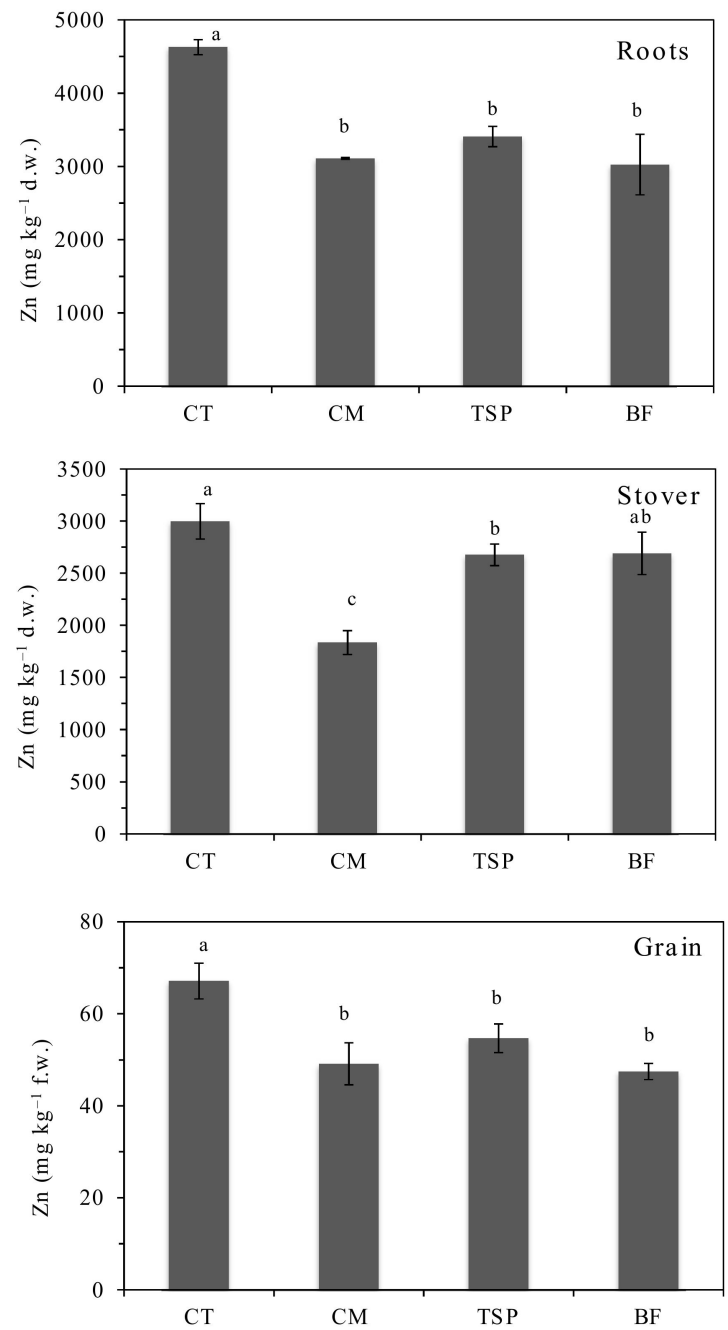

Figure 3. Concentrations of zinc (Zn), in maize roots, stover and grain in plots amended with chicken manure (CM), triple superphosphate (TSP) and blended fertilizer (BF; a mixture of NPK fertilizer and chicken manure) compared to the control (CT). Concentrations in roots and stover are on dry matter weight (d.w) basis, but on fresh weight (f.w) basis in grain. Bars with different letters are significantly different $(p<0.05)$.

Chicken manure and TSP significantly increased Cd concentrations in the roots, while all the soil amendments decreased $\mathrm{Cd}$ concentrations in the stover compared to the control (Figure 4). Cadmium concentrations in maize grain were significantly higher $(p<0.05)$ in TSP amended plots than other amendments including the control. The maize grain $\mathrm{Cd}$ concentrations ranged from 1.7-2.4, 0.8-1.5, 2.4-5.6 and 1.8-2.9 $\mathrm{mg} \mathrm{kg}^{-1}$ in the un-amended control, CM, TSP and BF treatments, respectively. Cadmium accumulation in maize grain in $\mathrm{CM}, \mathrm{BF}$ and control was not significantly different, but the 
mean maize grain $\mathrm{Cd}$ concentration in $\mathrm{CM}$ was lower than that in the control. Cadmium concentrations in the grain were 20,11, 41 and 23 times higher than the joint FAO/WHO maximum limit of $0.1 \mathrm{mg}$ $\mathrm{kg}^{-1}$ in the control, CM, TSP and BF treatments respectively.
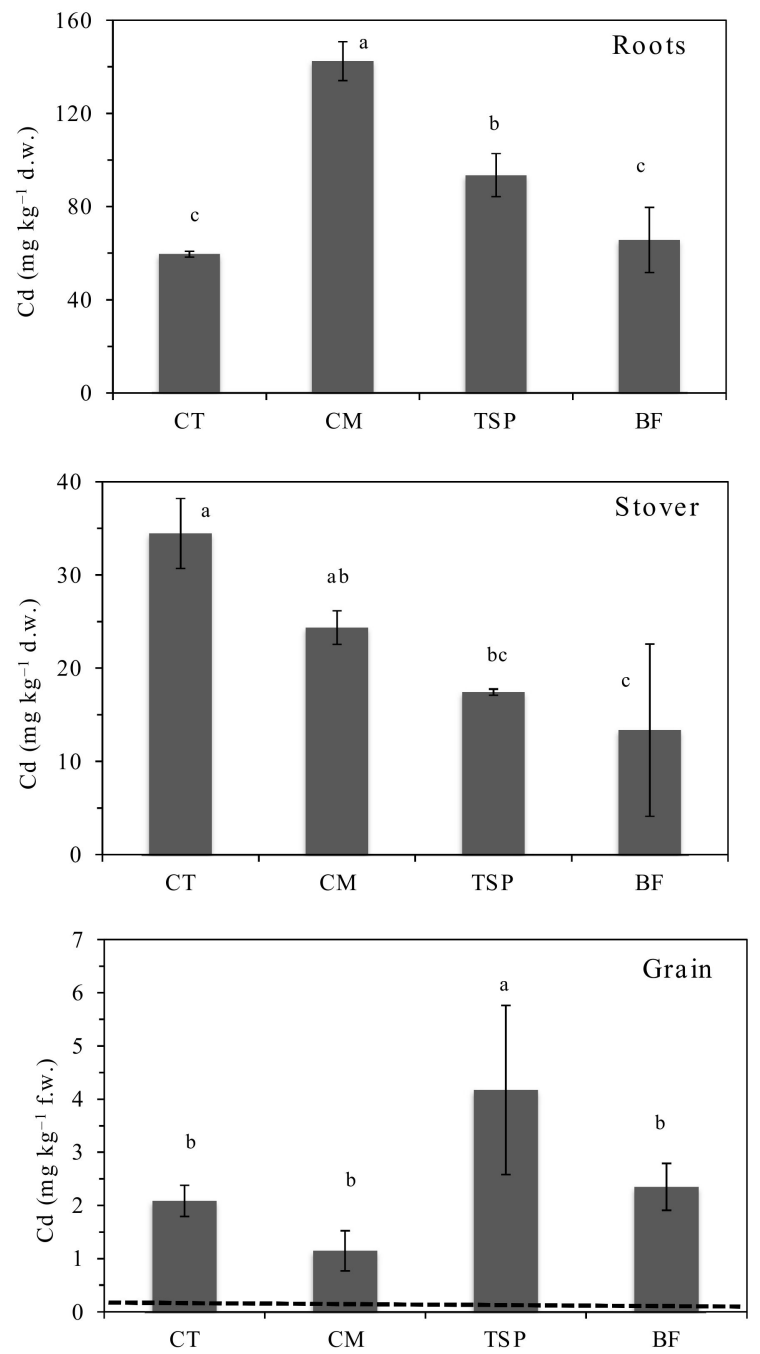

Figure 4. Concentrations of cadmium (Cd), in maize roots, stover and grain in plots amended with chicken manure (CM), triple superphosphate (TSP) and blended fertilizer (BF; a mixture of NPK and chicken manure). The horizontal broken line indicates the FAO/WHO maximum allowable limit of $0.1 \mathrm{mg} \mathrm{Cd} \mathrm{kg}^{-1}$ maize grain for human health. Concentrations in roots and stover are on dry matter weight (d.w) basis, but on fresh weight (f.w) basis in grain. Bars with different letters are significantly different $(p<0.05)$.

Lead concentrations in maize grain were positively correlated with $\mathrm{Pb}$ concentrations in soil and stover, but not with $\mathrm{Pb}$ concentrations in roots (Table 3). There was no correlation between $\mathrm{Zn}$ concentrations in maize grain and $\mathrm{Zn}$ concentrations in soil, but $\mathrm{Zn}$ concentrations in the roots had positive correlations with $\mathrm{Zn}$ in the stover. The biomass production was negatively correlated with $\mathrm{Zn}$ and $\mathrm{Pb}$ concentrations in the stover and grain, but only weakly, and not statistically significant, correlated with HM concentrations in the soil (Table 3). 
Table 3. Correlations between metal concentrations in soil and plant parts and biomass yield.

\begin{tabular}{|c|c|c|}
\hline & $\mathrm{Pb}$ Grain & Yield \\
\hline Pb soil & 0.59 * & -0.45 \\
\hline $\mathrm{Pb}$ roots & $-0.03^{\mathrm{ns}}$ & $0.06^{\mathrm{ns}}$ \\
\hline $\mathrm{Pb}$ stover & $0.74^{* *}$ & -0.61 * \\
\hline \multirow[t]{2}{*}{$\mathrm{Pb}$ grain } & 1 & $-0.92^{* * *}$ \\
\hline & Zn Grain & Yield \\
\hline Zn soil & $0.04^{\mathrm{ns}}$ & $-0.26^{\mathrm{ns}}$ \\
\hline $\mathrm{Zn}$ roots & $0.86^{* * *}$ & $-0.66^{* *}$ \\
\hline Zn stover & 0.60 * & $-0.66^{* *}$ \\
\hline \multirow[t]{2}{*}{ Zn grain } & 1 & $-0.75^{* * *}$ \\
\hline & Cd Grain & Yield \\
\hline Cd soil & $-0.30^{\mathrm{ns}}$ & $0.18^{\mathrm{ns}}$ \\
\hline Cd roots & $-0.28^{\mathrm{ns}}$ & $0.38^{\mathrm{ns}}$ \\
\hline Cd stover & $-0.33^{\mathrm{ns}}$ & $-0.41^{\mathrm{ns}}$ \\
\hline Cd grain & 1 & $-0.47^{\mathrm{ns}}$ \\
\hline
\end{tabular}

\subsection{Effect of Soil Amendments on Bioaccumulation Factors of $\mathrm{Pb}, \mathrm{Zn}$ and $\mathrm{Cd}$}

The bioaccumulation factors (BAF) of the stover and grain, which indicate the transfer of HMs from soil into above-ground plant parts, are shown in Figure 5. There was a 6-fold reduction in the $\mathrm{BAF}_{\mathrm{Pb}}$ of maize stover with the application of soil amendments. Chicken manure and BF resulted in 8and 5-fold reductions in the $\mathrm{BAF}_{\mathrm{Pb}}$ in the maize grain, while TSP had a 19\% reduction compared to the control. Soil amendments significantly decreased the $\mathrm{BAF}_{\mathrm{Zn}}$ of the stover and grain, except for TSP in stover (Figure 5). The soil amendments significantly decreased the $\mathrm{BAF}_{\mathrm{Cd}}$ in maize stover, but TSP increased the $\mathrm{BAF}_{\mathrm{Cd}}$ in the maize grain. Overall, the $\mathrm{BAF}$ values were in the order $\mathrm{Zn} \geq \mathrm{Cd}>\mathrm{Pb}$.

\subsection{Estimated Dietary Intake and Hazard Quotient Assessment of Pb and Cd}

A preliminary hazard assessment for human $\mathrm{Pb}$ and $\mathrm{Cd}$ ingestion through consumption of maize grain is shown in Table 4. The assessment was based on the assumption that daily intake of maize grain for an average adult Zambian weighing $70 \mathrm{~kg}$ is $350 \mathrm{~g} \mathrm{day}^{-1}$ [42]. The estimated weekly $\mathrm{Pb}$ ingestion from maize consumption was highest in the un-amended control soils and lowest from soils amended with chicken manure. Although higher than the joint FAO/WHO maximum tolerable $\mathrm{Pb}$ weekly intake of $0.025 \mathrm{mg} \mathrm{kg}^{-1}$ human body weight (HBW), estimated weekly Pb ingestion decreased by $83 \%, 27 \%$ and $75 \%$ with application of CM, TSP and BF, respectively.

The estimated monthly Cd ingestion from maize grain consumption increased by $100 \%$ with the application of TSP compared to the control. Chicken manure reduced the estimated monthly Cd ingestion by $40 \%$ compared to the control. This difference was however not statistically significant. The monthly $\mathrm{Cd}$ ingestion in all treatments was higher than the joint FAO/WHO maximum tolerable limit of $0.025 \mathrm{mg} \mathrm{Cd} \mathrm{kg}^{-1} \mathrm{HBW}$.

The HQ values for both $\mathrm{Pb}$ and $\mathrm{Cd}$ in all treatments were much greater than 1 , indicating that the maize grain grown in these soils was not safe for human consumption (Table 4). However, the HQ values for $\mathrm{Pb}$ were significantly reduced in plots with $\mathrm{CM}$ and $\mathrm{BF}$. Plots with TSP had the highest HQ values for $\mathrm{Cd}$. 

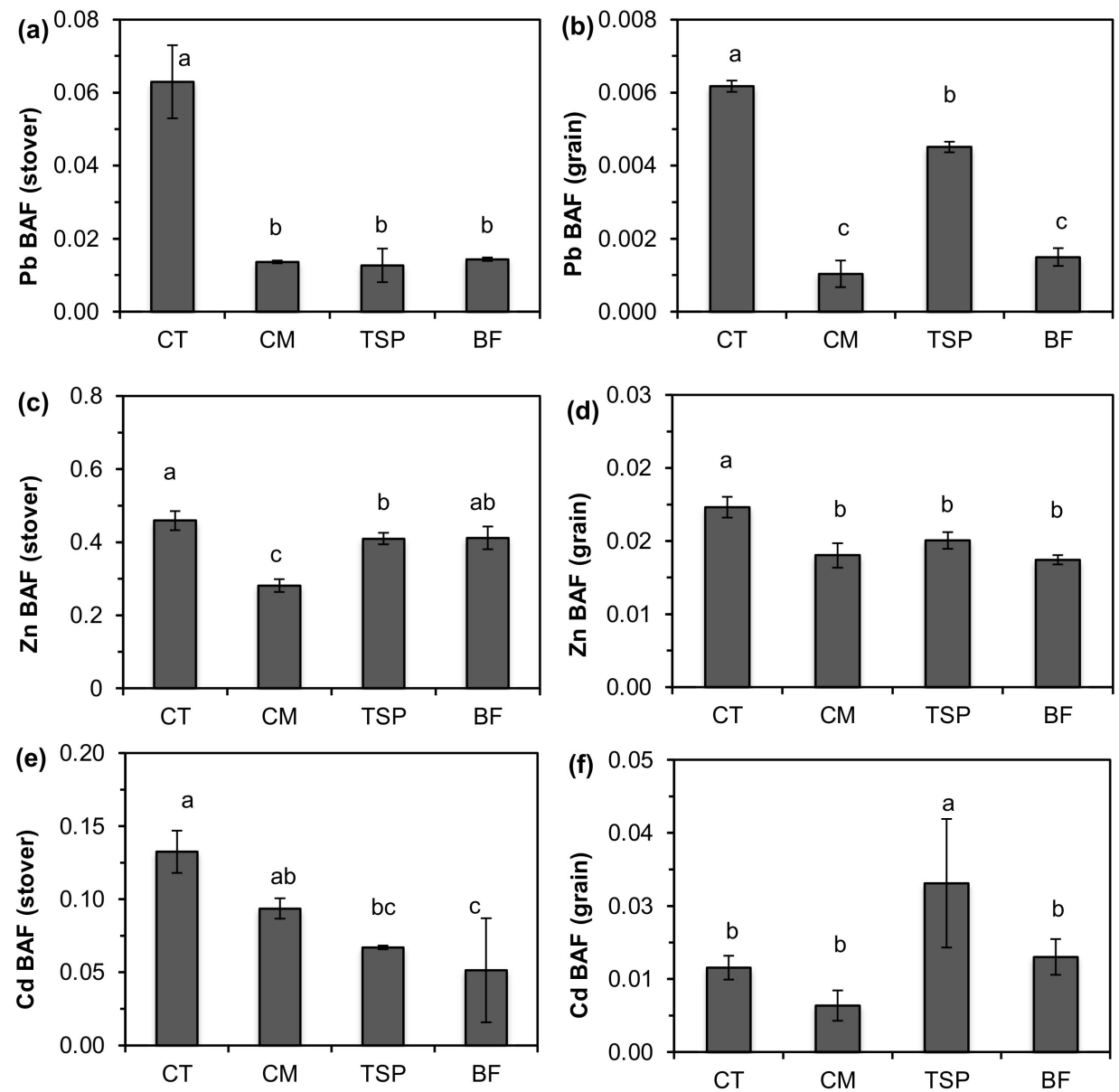

Figure 5. Bioaccumulation values for $(\mathbf{a}, \mathbf{b}) \mathrm{Pb} ;(\mathbf{c}, \mathbf{d}) \mathrm{Zn} ;(\mathbf{e}, \mathbf{f}) \mathrm{Cd}$ of maize stover and grain in plots amended with chicken manure (CM), triple superphosphate (TSP) and blended fertilizer (BF; a mixture of NPK fertilizer and chicken manure) and the control (CT). Bars with different letters are significantly different $(p<0.05)$.

Table 4. Estimated weekly $\mathrm{Pb}$ and monthly $\mathrm{Cd}$ intakes (EI) and hazard quotient (HQ) for raw uncooked maize grain grown in plots with different soil amendments compared to joint United Nations Food and Agricultural Organization (FAO)/WHO food tolerable intake limits [41].

\begin{tabular}{cccccc}
\hline & CT $^{+}$ & CM & TSP & BF & FAO/WHO Limit \\
\hline $\mathrm{EI}_{\mathrm{Pb}}(\mathrm{mg} / \mathrm{kg} \mathrm{HBW} /$ week $)$ & $0.99 \pm 0.02^{\mathrm{a}}$ & $0.16 \pm 0.05^{\mathrm{b}}$ & $0.72 \pm 0.02^{\mathrm{a}}$ & $0.24 \pm 0.04^{\mathrm{b}}$ & 0.025 \\
$\mathrm{EI}_{\mathrm{Cd}}(\mathrm{mg} / \mathrm{kg} \mathrm{HBW} /$ month $)$ & $0.31 \pm 0.04^{\mathrm{b}}$ & $0.17 \pm 0.05^{\mathrm{b}}$ & $0.62 \pm 0.23^{\mathrm{a}}$ & $0.35 \pm 0.06^{\mathrm{b}}$ & 0.025 \\
$\mathrm{HQ}$ & $39.6 \pm 1.0^{\mathrm{a} b}$ & $6.6 \pm 2.3^{\mathrm{b}}$ & $28.9 \pm 0.9^{\mathrm{a}}$ & $9.6 \pm 1.5^{\mathrm{b}}$ & \\
$\mathrm{HQ}_{\mathrm{Cd}}$ & $12.5 \pm 1.7^{\mathrm{b}}$ & $6.8 \pm 2.3^{\mathrm{b}}$ & $25.0 \pm 9.5^{\mathrm{a}}$ & $14.1 \pm 2.6^{\mathrm{b}}$ & \\
\hline
\end{tabular}

${ }^{+} \mathrm{CT}$ is the control, CM is chicken manure, TSP is triple superphosphate, BF is blended fertilizer (mixture of NPK fertilizer and chicken manure) treatments. Means with different superscripts within each row are significantly different at $p<0.05$.

\section{Discussion}

\subsection{Effects of Soil Amendments on Heavy Metal Bioavailability and Plant Uptake}

The reduction in bioavailable HMs in the soil after application of manure and $\mathrm{P}$ based amendments has been reported by other studies [4,22-24]. Contrary to other studies (e.g., Putwattana et al., 2015), no significant reduction in bioavailable $\mathrm{Cd}$ and $\mathrm{Zn}$ concentrations were observed after applying inorganic $\mathrm{P}$ amendments in this study. This finding is in agreement with that of a laboratory study by Bohdan et al. (2019) who reported that inorganic P amendment decreased concentrations of 
bioavailable $\mathrm{Pb}$ but not $\mathrm{Zn}$, and that humate application did not affect bioavailable $\mathrm{Zn}$ and $\mathrm{Cd}$ in Kabwe soils. Unlike the findings of Bohdan et al. (2019), in this study bioavailable (DTPA-TEA extractable) Cd did not decrease after applying inorganic $P$ amendments. Results of this study suggest that a single amendment was unlikely to decrease the bioavailability of all the three HMs of concern in Kabwe, and therefore future studies should look at different combinations of these amendments.

The decreased uptake of $\mathrm{Pb}$ and $\mathrm{Zn}$ in the maize in the amended soils was likely due to their immobilization in the soil through the formation of insoluble precipitates or complexes [23,24], or due to fixation to organic matter functional groups [9], or ion exchange due to increased soil surface charge [23] following application of organic amendments like CM and BF. Despite increasing $\mathrm{Pb}$ concentration in plant roots, the phosphate and organic amendments reduced $\mathrm{Pb}$ translocation from the roots to shoots. This could be due to the formation of pyromorphite-like minerals on the root membrane surface [24] or to inhibited metal transfer within the plant [23].

The reduction of $\mathrm{HM}$ concentrations in maize stover and grain in plots amended with $\mathrm{CM}$, TSP and BF (Figures 2-4) could also have been due to the "growth dilution effect" [4,23] following higher biomass production compared to the control. In this study, the maize biomass yield in plots amended with CM and BF was 25 times higher, while the biomass in the plots with TSP was 6 times higher than that in the control (Table 2). Increased plant growth, which likely resulted from the increased availability of plant nutrients in the soil and decreased plant stress due to reduced soil HM bioavailability, could have reduced the concentration of the HMs in the aboveground plant parts. The observed higher Cd concentrations in the maize grain from plots with TSP and BF amended soils than that in the control (Figure 4) was likely due to the reported increased solubility of $\mathrm{Cd}$ in the presence of phosphate compounds [22]. Some Cd-phosphate complexes are reported to have relatively high solubility in the presence of high phosphate [22], making the Cd more mobile.

Other studies have suggested that inorganic phosphate fertilizers increase $\mathrm{Cd}$ uptake in plants due to the introduction $\mathrm{Cd}$ to the soil by fertilizers [14,22]. Studies have shown that inorganic phosphate fertilizers tend to increase $\mathrm{Cd}$ concentrations in soils [14,22], because some rock phosphates used to produce phosphate fertilizers contain high levels of $\mathrm{Cd}$. It is unlikely that increased $\mathrm{Cd}$ the maize grain could have resulted from the fertilizers because the $\mathrm{Cd}$ concentrations in all three amendments were below the detection limit in the current study. However, this cannot be ruled out completely.

The soil-to-plant bioaccumulation factors of all three HMs were higher for maize stover than for grain, indicating a possible defense mechanism against the translocation of excess HMs into grains [40]. The general trend was that $\mathrm{Zn}$ showed the highest bioaccumulation factors while $\mathrm{Pb}$ had the lowest. However, in the maize grain, the bioaccumulation factors for $\mathrm{Cd}$ were either of similar magnitude or even higher than those for $\mathrm{Zn}$. This suggests that once in the plant, $\mathrm{Cd}$ had a higher ability for translocation than both $\mathrm{Zn}$ and $\mathrm{Cd}$. High Cd mobility in plants has been reported by Bi et al. [10].

\subsection{Health Risk Assessment}

The concentrations of $\mathrm{Pb}$ and $\mathrm{Cd}$ in the maize grain (Figures 2 and 4) were higher than the Joint FAO/WHO Codex Alimentarius Commission [41] limits for food safety. In the un-amended soil, the $\mathrm{Pb}$ concentrations in the maize grain were more than 100 times higher than the joint $\mathrm{FAO} / \mathrm{WHO}$ maximum permissible limit of $0.2 \mathrm{mg} \mathrm{kg}^{-1}$ for health safety but decreased significantly (only 24 times higher) in the chicken manure amended plots. High $\mathrm{Pb}$ and $\mathrm{Cd}$ concentrations in maize in Kabwe was previously reported by Nakata et al. [44]. These high concentrations resulted in high estimated intake (EI) values as well as hazard quotients (HQ). The HQ values were higher than 1 (Table 4), indicating significant human health risk. Higher $\mathrm{HQ}$ values near former mining sites have been reported by other studies $[5,10,40]$. Despite relatively low Cd concentrations in the soils, Cd concentrations in the maize grain were high. This could be due to the reported high mobility and transfer of $\mathrm{Cd}$ from soil into plants [5].

Maize is widely grown and consumed in areas surrounding the old Kabwe mine and throughout Zambia. Results of this study have shown that the concentrations of $\mathrm{Pb}$ and $\mathrm{Cd}$ in maize grain grown 
on soils near the former Kabwe $\mathrm{Pb} / \mathrm{Zn}$ mine were higher than the maximum tolerable limits for food safety and human health. It is therefore clear, from this study, that the risk of human exposure to toxic levels of $\mathrm{Pb}$ and $\mathrm{Cd}$ by consuming maize grown in areas surrounding the mine is very high. This study also demonstrated that there is a high potential to reduce this risk by applying amendments such as chicken manure and phosphate-based fertilizers to these soils. Because this study was conducted at a site within $500 \mathrm{~m}$ from the old $\mathrm{Pb}-\mathrm{Zn}$ mine with very high $\mathrm{HM}$ concentrations [30], it is possible that on sites much further away from the mine, the application of amendments tested in this study could potentially decrease HM concentrations to below the maximum tolerable limits and further reduce the hazard quotients. Additionally, these results are useful to various parts of Zambia and the world at large, where contamination exists either from mining or other sources such as pesticide use [4]. Compared to phosphate fertilizer, chicken manure is relatively widely available and cheaper for most local residents in low-income mining townships in Zambia where backyard gardening is widely practiced. Hence using chicken manure could not only reduce the HM accumulation in edible crops but also to increase productivity and is a potentially low-cost management option.

The observed high health risk of $\mathrm{Cd}$ requires that serious attention be paid to the problem of $\mathrm{Cd}$ pollution, which has currently been overshadowed by that of $\mathrm{Pb}$, owing to the higher concentrations of $\mathrm{Pb}$ than $\mathrm{Cd}$ in Kabwe soils. Therefore, while $\mathrm{Pb}$ receives its due attention by researchers, health and civic authorities and the public at large, the problems posed by $\mathrm{Cd}$ in the environment should equally be of concern in Kabwe.

\section{Conclusions}

All three soil amendments (chicken manure, triple superphosphate and NPK fertilizer mixed with chicken manure) decreased bioavailable soil $\mathrm{Pb}$ concentrations, but only chicken manure decreased $\mathrm{Zn}$ and $\mathrm{Cd}$ in soil compared to the control. The soil amendments reduced $\mathrm{Pb}$ and $\mathrm{Zn}$ concentrations in the maize stover and grain. Amendments containing inorganic phosphate increased $\mathrm{Cd}$ concentrations in maize grain. The health risk assessment reviewed that $\mathrm{Pb}$ and $\mathrm{Cd}$ concentrations in maize, and the resulting estimated weekly and monthly metal intakes exceeded the FAO/WHO limits. The hazard quotients for $\mathrm{Pb}$ and $\mathrm{Cd}$ indicated that there is a high health risk to people who consume maize grain grown on the soils in the study area. Results of this study have demonstrated that the use of chicken manure and phosphate-based soil amendments have significant potential to reduce the concentrations of $\mathrm{Pb}, \mathrm{Zn}$ and $\mathrm{Cd}$ in maize grown in the study area and consequently reduce related health risks associated with the consumption of the maize.

Author Contributions: Conceptualization, I.M. and P.N.M.; formal analysis, P.N.M. and I.M.; investigation, P.N.M. and I.M.; data curation, I.M., P.N.M. and Y.U.; writing-original draft preparation, I.M.; writing-review and editing, I.M., V.S., Y.U., B.H.C., H.N., S.N.; visualization, I.M.; supervision, Y.U., B.H.C., V.S.; project administration, M.I., H.N., S.N.; funding acquisition, M.I. All authors have read and agreed to the published version of the manuscript.

Funding: This study was financially supported by Japan Science and Technology Agency (JST) and Japan International Cooperation Agency (JICA), Science and Technology Research Partnership for Sustainable Development (SATREPS), No. JPMJSA1501, and JST aXis (Accelerating Social Implementation for Sustainable Development Goals (SDGs) Achievement; No. JPMJAS2001).

Acknowledgments: The authors are thankful to the Kabwe Municipal Council for their support to this study.

Conflicts of Interest: The authors declare no conflict of interest. The funders had no role in the design of the study; in the collection, analyses, or interpretation of data; in the writing of the manuscript, or in the decision to publish the results.

\section{References}

1. Puga, P.A.; Melo, C.L.A.; Abreu, A.C.; Coscione, R.A.; Paz-ferreiro, J. Leaching and fractionation of heavy metals in mining soils amended with biochar. Soil Tillage Res. 2016, 164, 25-33. [CrossRef]

2. Tóth, G.; Hermann, T.; Da Silva, M.R.; Montanarella, L. Heavy metals in agricultural soils of the European Union with implications for food safety. Environ. Int. 2016, 88, 299-309. [CrossRef] [PubMed] 
3. Shi, G.; Chen, Z.; Xu, S.; Zhang, J.; Wang, L.; Bi, C.; Teng, J. Potentially toxic metal contamination of urban soils and roadside dust in Shanghai, China. Environ. Pollut. 2008, 156, 251-260. [CrossRef] [PubMed]

4. Paltseva, A.; Cheng, Z.; Deeb, M.; Groffman, P.M.; Shaw, R.K.; Maddaloni, M. Accumulation of arsenic and lead in garden-grown vegetables: Factors and mitigation strategies. Sci. Total Environ. 2018, 640, $273-283$. [CrossRef] [PubMed]

5. Zhuang, P.; Mcbride, M.B.; Xia, H.; Li, N.; Li, Z. Health risk from heavy metals via consumption of food crops in the vicinity of Dabaoshan mine, South China. Sci. Total Environ. 2009, 407, 1551-1561. [CrossRef] [PubMed]

6. Cai, Q.; Long, M.; Zhu, M.; Zhou, Q.; Zhang, L.; Liu, J. Food chain transfer of cadmium and lead to cattle in a lead-zinc smelter in Guizhou, China. Environ. Pollut. 2009, 157, 3078-3082. [CrossRef]

7. Luo, L.; Ma, Y.; Zhang, S.; Wei, D.; Zhu, Y. An inventory of trace element inputs to agricultural soils in China. J. Environ. Manag. 2009, 90, 2524-2530. [CrossRef]

8. Rai, K.P.; Sang, L.S.; Zhang, M.; Tsang, F.Y.; Kim, K. Heavy metals in food crops: Health risks, fate, mechanisms, and management. Environ. Int. 2019, 125, 365-385. [CrossRef]

9. Khan, A.; Khan, S.; Khan, M.A.; Qamar, Z.; Waqas, M. The uptake and bioaccumulation of heavy metals by food plants, their effects on plants nutrients, and associated health risk: A review. Environ. Sci. Pollut. Res. 2015, 22, 13772-13799. [CrossRef]

10. Bi, C.; Zhou, Y.; Chen, Z.; Jia, J.; Bao, X. Heavy metals and lead isotopes in soils, road dust and leafy vegetables and health risks via vegetable consumption in the industrial areas of Shanghai, China. Sci. Total Environ. 2018, 619-620, 1349-1357. [CrossRef]

11. Abbas, Q.; Yousaf, B.; Liu, G.; Zia-ur-rehman, M.; Ali, M.U.; Munir, M.A.M.; Hussain, S.A. Evaluating the health risks of potentially toxic elements through wheat consumption in multi-industrial metropolis of Faisalabad, Pakistan. Environ. Sci. Pollut. Res. 2017, 24, 26646-26657. [CrossRef] [PubMed]

12. Adejumo, S.A.; Ogundiran, M.B.; Togun, A.O. Soil amendment with compost and crop growth stages influenced heavy metal uptake and distribution in maize crop grown on lead-acid battery waste contaminated soil. J. Environ. Chem. Eng. 2018, 6, 4809-4819. [CrossRef]

13. Oka, M.; Uchida, Y. Heavy metals in slag affect inorganic $\mathrm{N}$ dynamics and soil bacterial community structure and function. Environ. Pollut. 2018, 243, 713-722. [CrossRef] [PubMed]

14. UNEP. Environmental Risks and Challenges of Anthropogenic Metals Flows and Cycles. In A Report of the Working Group on the Global Metal Flows to the International Resource Panel; van der Voeat, E., Salminen, R., Eckelman, M., Mudd, G., Norgate, T., Hischier, R., Eds.; UNEP: Nairobi, Kenya, 2013.

15. Chibuike, G.U.; Obiora, S.C. Heavy Metal Polluted Soils: Effect on Plants and Bioremediation Methods. Appl. Environ. Soil Sci. 2014, 2014, 243-254. [CrossRef]

16. Caravanos, J.; Kevin, C.; Bret, E.; Landrigan, P.J.; Richard, F. The burden of disease from pediatric lead exposure at hazardous waste sites in 7 Asian countries. Environ. Res. 2013, 120, 119-125. [CrossRef]

17. Voegelin, A.; Tokpa, G.; Jacquat, O.; Barmettler, K.; Kretzschmar, R. Zinc Fractionation in Contaminated Soils by Sequential and Single Extractions: Influence of Soil Properties and Zinc Content. J. Environ. Qual. 2008, 37, 1190-1200. [CrossRef]

18. Spliethoff, H.M.; Mitchell, R.G.; Shayler, H.; Marquez-bravo, L.G.; Russell-Anelli, J.; Ferenz, G.; Mcbride, M. Estimated lead $(\mathrm{Pb})$ exposures for a population of urban community gardeners. Environ. Geochem. Health 2017, 38, 955-971. [CrossRef]

19. Suelee, A.L.; Hasan, S.N.S.M.; Kusin, F.M.; Yusuff, F.M.; Ibrahim, Z.Z. Phytoremediation Potential of Vetiver Grass (Vetiveria zizanioides) for Treatment of Metal-Contaminated Water. Water Air Soil Pollut. 2017, 228, 158. [CrossRef]

20. Paltseva, A.A.; Cheng, Z.; Egendorf, S.P.; Groffman, P.M. Remediation of an Urban Garden with Elevated Levels of Soil Contamination. Sci. Total Environ. 2020, 722, 137965. [CrossRef]

21. Mcbride, M.B.; Richards, B.K.; Steenhuis, T. Bioavailability and crop uptake of trace elements in soil columns amended with sewage sludge products. Plant. Soil 2004, 262, 71-84. [CrossRef]

22. Mahar, A.; Wang, P.; Li, R.; Zhang, Z. Immobilization of Lead and Cadmium in Contaminated Soil Using Amendments: A Review. Pedosphere 2015, 25, 555-568. [CrossRef]

23. Gao, W.; Zhao, P.; Sui, F.; Liu, H.; Fu, H. Influence of Soil Amendments on Uptake and Accumulation of Cd and $\mathrm{Pb}$ in Maize (Zea mays L.). Environ. Eng. Sci. 2018, 35, 194-202. [CrossRef] 
24. Cao, R.X.; Ma, L.Q.; Chen, M.; Singh, S.P.; Harris, W.G. Phosphate-induced metal immobilization in a contaminated site. Environ. Pollut. 2003, 122, 19-28. [CrossRef]

25. Bernardino, C.A.R.; Mahler, C.F.; Preussler, K.H.; Novo, L.A. State of the Art of Phytoremediation in Brazil-Review and Perspectives. Water Air Soil Pollut. 2016, 227, 272. [CrossRef]

26. Osmond, G.; Hamon, R.E. Remediation of polluted soils. In Encyclopedia of Soils in the Environment; Hillel, D., Ed.; Elsevier: Amsterdam, The Netherlands, 2004; pp. 379-385.

27. Munir, M.A.M.; Liu, G.; Yousaf, B.; Mian, M.; ALi, U.M.; Ahmed, R.; Cheema, I.A.; Naushad, M. Contrasting effects of biochar and hydrothermally treated coal gangue on leachability, bioavailability, speciation and accumulation of heavy metals by rapeseed in copper mine tailings. Ecotoxicol. Environ. Saf. 2020, 191, 110244. [CrossRef]

28. Adejumo, S.A.; Togun, A.O.; Adediran, A.J.; Ogundiran, M.B. Field Assessment of Progressive Remediation of Soil Contaminated with Lead-acid Battery Waste in Response to Compost Application. Pedologist 2011, 54, 182-193.

29. Putwattana, N.; Kruatrachue, M.; Kumsopa, A.; Pokethitiyook, P. Evaluation of Organic and Inorganic Amendments on Maize Growth and Uptake of $\mathrm{Cd}$ and $\mathrm{Zn}$ from Contaminated Paddy Soils. Int. J. Phytoremediat. 2015, 17, 165-174. [CrossRef]

30. Bohdan, K.; Nyambe, I.; Majer, V.; Knésl, I.; Mihaljevi, M.; Pení, V.; Sracek, O. Soil contamination near the Kabwe $\mathrm{Pb}-\mathrm{Zn}$ smelter in Zambia: Environmental impacts and remediation measures proposal. J. Geochemical Explor. 2019, 197, 159-173.

31. Yabe, J.; Nakayama, S.M.M.; Ikenaka, Y.; Yohannes, Y.B.; Bortey-sam, N.; Nketani, A.; Ntapisha, J.; Mizukawa, H.; Umemura, T.; Ishizuka, M. Lead and cadmium excretion in feces and urine of children from polluted townships near a lead-zinc mine in Kabwe, Zambia. Chemosphere 2018, 202, 48-55. [CrossRef]

32. Yabe, J.; Nakayama, S.M.M.; Ikenaka, Y.; Yohannes, Y.B.; Bortey-sam, N.; Oroszlany, B.; Muzandu, K.; Choongo, K.; Nketani, A.; Ntapisha, J.; et al. Lead poisoning in children from townships in the vicinity of a lead-Zinc mine in Kabwe, Zambia. Chemosphere 2015, 119, 941-947. [CrossRef]

33. Cachada, A.; Rocha-santos, T.; Duarte, A.C. Soil and Pollution: An Introduction to the Main Issues; Duarte, A.C., Cachada, A., Rocha-Santos, T., Eds.; Academic Press: Cambridge, MA, USA, 2018.

34. Ministry of Agriculture. Exploratory Soil Map of Zambia. Scale 1: 1,000,000; Ministry of Agriculture: Lusaka, Zambia, 1991.

35. Hettiarachchi, G.M.; Pierzynski, G.M. Soil Lead Bioavailability and in Situ Remediation of Lead-Contaminated Soils: A Review. Environ. Prog. 2004, 23, 78-93. [CrossRef]

36. TerAvest, D.; Carpenter-Boggs, L.; Thierfelder, C.; Reganold, J.P. Crop production and soil water management in conservation agriculture, no-till, and conventional tillage systems in Malawi. Agric. Ecosyst. Environ. 2015, 212, 285-296. [CrossRef]

37. Clark, H.F.; Hausladen, D.M.; Brabander, D.J. Urban gardens: Lead exposure, recontamination mechanisms, and implications for remediation design. Environ. Res. 2008, 107, 312-319. [CrossRef] [PubMed]

38. Roy, R.N.; Finck, A.; Blair, G.J.; Tandon, H.L.S. Plant Nutrition for Food Security: FAO Fertilizer and Plant Nutrition Bulletin 16; United Nations Food and Agricultural Organization (FAO): Rome, Italy, 2006.

39. Lindsay, W.; Norvell, W. Development of a DTPA Soil Test for Zinc, Iron, Manganese, and Copper. Soil Sci. Soc. Am. J. 1978, 42, 421-428. [CrossRef]

40. Antoniadis, V.; Golia, E.E.; Liu, Y.; Wang, S.; Shaheen, S.M.; Rinklebe, J. Soil and maize contamination by trace elements and associated health risk assessment in the industrial area of Volos, Greece. Environ. Int. 2019, 124, 79-88. [CrossRef] [PubMed]

41. Joint FAO/WHO. Codex Alimentarius Commission General Standard for Contaminants and Toxins in Food and Feed (CXS 193-1995); FAO: Rome, Italy, 2018.

42. Alaofe, H.; Kohler, L.; Taren, D.; Mofu, M.J.; Chileshe, J.; Kalungwana, N. Zambia Food Consumption and Nutrition Survey Report; National Food and Nutrition Commission: Lusaka, Zambia, 2014.

43. Kribek, B.; Majer, V.; Knésl, I.; Nyambe, I.; Mihaljevic, M.; Ettler, V.; Sracek, O. Concentrations of arsenic, copper, cobalt, lead and zinc in cassava (Manihot esculenta Crantz) growing on uncontaminated and contaminated soils of the Zambian Copperbelt. J. Afr. Earth Sci. 2014, 99, 713-723. [CrossRef] 
44. Nakata, H.; Nakayama, S.M.M.; Yabe, J.; Liazambi, A.; Mizukawa, H.; Darwish, W.S.; Ikenaka, Y.; Ishizuka, M. Reliability of stable $\mathrm{Pb}$ isotopes to identify $\mathrm{Pb}$ sources and verifying biological fractionation of $\mathrm{Pb}$ isotopes in goats and chickens. Environ. Pollut. 2016, 208, 395-403. [CrossRef]

Publisher's Note: MDPI stays neutral with regard to jurisdictional claims in published maps and institutional affiliations.

(C) 2020 by the authors. Licensee MDPI, Basel, Switzerland. This article is an open access article distributed under the terms and conditions of the Creative Commons Attribution (CC BY) license (http://creativecommons.org/licenses/by/4.0/). 